\title{
Developing your career as a general practitioner
}

\author{
Jacqui Wise \\ London, UK
}

General practice offers plenty of opportunities for career development. Many GPs choose to work one or two sessions a week in a different role-for example, teaching, research, writing, or getting involved in medical politics. GPs can also work in a variety of settings outside of a normal practice or health centre, including prisons, hospices, or in the military.

\section{Developing a special interest}

GPs with extended roles (GPwERs) take on roles that need additional training. This means they can take referrals for patients who may otherwise have been sent to a secondary care consultant or provide an enhanced service for a particular condition or patient group. The term GPwER includes those previously referred to as a GP with special interest (GPwSI). Special interests can include areas such as asthma, diabetes, palliative medicine, minor surgical procedures, and musculoskeletal medicine. The Royal College of General Practitioners is currently trialling a national process of accreditation for GPs with extended scopes of practice in dermatology and skin surgery (www.rcgp.org.uk/training-exams/ practice/general-practitioners-with-extended-roles.aspx). GPs may start by taking the lead for a particular clinical area within their practice by undertaking further courses or research. They may then go on to work with other practices or the clinical commissioning group and help to develop local guidelines, services, and pathways of care. GPs can also develop their specialist knowledge by becoming a clinical assistant to a consultant in a hospital outpatient clinic

\section{Teaching}

GPs can become vocational trainers to help and support the next generation of general practice trainees. GPs must have been qualified for two years and gained either a postgraduate certificate in medical education or have attended an intensive residential course. More details can be found by contacting the local GP specialty training programme director at your deanery.

\section{Academia}

Recruitment to academic GP training is different in each country within the UK. Entry into an academic career would usually start with a clinical fellowship and may progress to a clinical lectureship (gprecruitment.hee.nhs.uk/Recruitment/Academic). Applications for entry into academic clinical fellow posts are coordinated by the National Institute for Health Research Trainees Coordinating Centre

\section{Working in the military}

The Defence Medical Services (DMS) employs military and civilian doctors to deliver medical support to the Royal Navy, the British army, and the Royal Air Force. Joining the DMS doesn't have to be a long term commitment-GPs can consider a short military commission as part of their career development. The process for joining as a doctor in the armed forces varies between the services. More information is available on the DMS website (www.gov.uk/government/groups/defence-medicalservices) and the BMA website (www.bma.org.uk/advice/career/ progress-your-career/joining-the-armed-forces-reserves/howto-join).

\section{Medical politics}

GPs who are motivated to make a difference to patient care or to improve working conditions may want to get involved in medical politics. Useful experience can be gained by working with the local medical committee, the BMA, the RCGP, or the GMC. GPs can also become involved with their local clinical commissioning group or other health service body.

\section{Journalism}

There are a number of opportunities for working in medical journalism. For example, GPs can write articles for their local paper or for specialist publications such as The BMJ. GPs may also be able to work for pharmaceutical companies or medical communications agencies.

\section{Expedition medicine}

Expedition medical officers support adventure travellers and overseas field researchers. The role involves pre-expedition planning and supporting people who become ill or injured. It may also involve arranging emergency transport for someone who is sick or wounded. GPs would need to take an expedition medicine course. Details of courses can be found at www. healthcareers.nhs.uk/explore-roles/doctors/career-opportunitiesdoctors/alternative-roles-doctors/expedition-medicine, https:// worldextrememedicine.com, or www.theadventuremedic.com.

\section{Sports medicine}

GPs with an interest in sport can get involved with their local or national sports team. Further training will be necessary, such as a diploma in sports and exercise medicine. Contact the faculty 
of sport and exercise medicine for more details (www.fsem.ac. uk).

\section{Prison medicine}

Working within prison healthcare can be challenging but rewarding. GPs can work either full or part time in prisons. No specific extra training is required; however, experience in treating communicable diseases, drug misuse, and mental ill health can be useful. Job adverts can be found on NHS Jobs (www.jobs.nhs.uk) and BMJ Careers (https://jobs.bmj.com).

\section{Working in a developing country}

There are opportunities for doctors to work in developing countries in emergency humanitarian assistance and more long term health programmes. Staff are often needed at short notice and work in challenging environments. Projects can be from six months to three years. It is recommended that you maintain your GMC registration if you are considering working abroad. Further information can be found at www.bma.org.uk/advice/ career/going-abroad/volunteering-abroad/gp. Opportunities can be found at Médecins Sans Frontières (www.msf.org.uk), MERLIN (www.merlin.org.uk), and Voluntary Service Overseas https://www.vsointernational.org.

\section{Career break}

Many GPs consider taking a break from clinical practice for various reasons including having a family or ill health. However, with the introduction of revalidation it is important to plan carefully for this and get further advice from a mentor or GP tutor. More details can be found at www.bma.org.uk/advice/ career/progress-your-career/career-break-gp-advice. 